\author{
Научная статья \\ УДК27:811.512.31(=512.31) \\ DOI: $10.18101 / 2305-459 X-2020-3-15-23$
}

\title{
ПИСЬМЕННОЕ НАСЛЕДИЕ БУРЯТ НА МОНГОЛЬСКОМ ПИСЬМЕ
}

\author{
(C) Бадмаева Лариса Батоевна \\ доктор филологических наук, доцент, \\ ведущий научный сотрудник отдела языкознания, \\ Институт монголоведения, буддологии и тибетологии Сибирского отделения РАН \\ Россия, 670047, г. Улан-Удэ, ул. Сахьяновой, 6 \\ lorabadm@mail.ru
}

\begin{abstract}
Аннотация. В статье исследуется летописное наследие бурят на старописьменном монгольском языке, который в течение долгого времени был общемонгольским литературным языком начиная с XII в. Как письменный литературный язык бурят использовался с XVII в. до 1936 г. На монгольском письме созданы уникальные сочинения разных жанров, велось делопроизводство и издавались газеты и журналы. Наиболее развит жанр исторических хроник. Традиция летописания у бурят продолжалась и в XX в. Описан ранее неисследованный анонимный письменный памятник начала 1920-х гг. «Ацагатский очерк о хори-бурятах». Данное сочинение, основанное на соединении традиций монгольских летописей и русской исторической науки, с элементами бурятского фольклора, этнографии, воспоминаний очевидцев, собственных наблюдений автора, представляет собой синтез жанров исторического, литературного, мемуарного характера. Смена письменности в последующие годы привела к полному забвению как авторов, так и самих памятников. Между тем эти письменные источники, являясь отражением языковой картины монгольского мира, представляют большой интерес для историков, филологов, культурологов.
\end{abstract}

Ключевые слова: монгольское вертикальное письмо; письменные памятники бурят; бурятские летописи; анонимный «Ацагатский очерк о хори-бурятах».

Благодарность. Статья подготовлена при финансовой поддержке гранта РФФИ18-012-00665a.

\section{Для цитирования}

Бадмаева Л. Б. Письменное наследие бурят на монгольском письме // Вестник Бурятского государственного университета. Язык. Литература. Культура. 2020. Вып. 3. C. 15-23.

В настоящее время комплексное изучение языка бурятских летописных текстов является чрезвычайно важной проблемой для полного представления о бурятской летописи как органичной части письменной культуры бурят. Изменения, происходящие в монголоведении в последние десятилетия, обусловленные стремлением понять место монгольской словесности в мировом литературном процессе, требуют рассмотрения особенностей становления и развития отдельных форм и жанров, их роли в формировании письменной традиции монгольских народов. 
Как известно, старописьменный монгольский язык в течение долгого времени был общемонгольским литературным языком, обслуживающим нужды собственно монголов, а также ойратских и бурятских племен. В настоящее время им активно пользуются как письменным литературным языком только во Внутренней Монголии Китая.

Старомонгольский язык использовался как в Бурятии, так и в Монголии в качестве языка средневековой науки. В бурятских дацанах издавались переводные и оригинальные труды по философии и логике, языкознанию и поэзии, медицине и прикладным наукам, астрономии и географии. Для перевода и написания научных сочинений в лексикографических трудах была разработана специальная терминология. Авторами таких сочинений, как правило, выступали ученые буддийские монахи. В результате обучения мальчиков в дацанах и зарубежных монастырях среди бурят появилась прослойка духовной интеллигенции.

На монгольском письме записывались улигеры (былины, сказания), песни и другие произведения устного народного творчества, делались переводы Библии и художественных произведений с русского языка (например, сказки А. С. Пушкина переводил Агван Доржиев), создавались произведения дидактического характера («Билиг-ун толи» Э.-Х. Галшиева и др.).

После вхождения бурят в подданство Российской империи монгол бичиг у забайкальских бурят использовался и для ведения делопроизводства. В уцелевших архивах Хоринской, Селенгинской, Агинской и Баргузинской степных дум сохранился значительный фонд материалов по истории хозяйства и управления бурят, написанных на монгольском письме. Кроме деловых писем (отношений, рапортов, уведомлений, донесений, предписаний, челобитных, жалоб, прошений и т. д.) на монгольском письме составлялись постановления сугланов (собраний) и официальные сборники обычного права, т. е. степные законы. Так, известны «Согласно принятое положение о правилах бурятского податного народа» (1749), Хоринские уложения 1763, 1781, 1808, 1823 гг., Селенгинские уложения 1775, 1823 гг. и другие юридические документы.

Буряты пользовались данным письмом (хуушан монгол бэшэг) вплоть до 30-х гг. XX в.: издавались газеты «Buriyad-Mongyol-un ünen» [16], «Жизнь на Восточной Окраине» (на русском и старомонгольском языках) и журналы «Teтес̌еlün čimeg», «Sine bayidal» и др. В этот период старописьменный монгольский язык обслуживает большинство сфер национальной жизни бурятского общества: публицистику, художественную литературу, государственное управление, делопроизводство, школьно-издательское дело, потребности агитации и пропаганды, просвещения [22].

По мнению Л. Д. Шагдарова, «в период употребления старописьменного языка в 20-х годах в нем проявились дифференциальные признаки, присущие обычно национальным литературным языкам: поливалентность, нормированность, наддиалектный характер и стилистическая дифференцированность» [20, c. 121-122].

Литературное наследие бурят на вертикальном монгольском письме включает в себя исторические, дидактические, медицинские, филологические, лексикографические, юридические, буддийские сочинения. Буряты в условиях кочево- 
го образа жизни сумели создать, сохранить и донести до наших дней уникальные памятники письменной культуры монголоязычных народов, среди которых особое место занимают исторические хроники.

Исследованию языка старописьменных памятников бурят посвящены труды Г. Н. Румянцева [15], Ц. Б. Цыдендамбаева [19], Д. Д. Доржиева [6; 7], Л. Д. Шагдарова [1], Г. Н. Очировой [2; 13], А. Д. Жамсоева [8-11] и др.

Бурятские исторические сочинения стали появляться в XVIII в. в связи с консолидацией бурят в самостоятельную народность и служили не только ценными источниками исторической и культурологической информации, но и значимыми оригинальными литературными памятниками.

Они пользовались большой популярностью среди бурятских читателей, имели хождение исключительно в рукописях, которые распространялись подвижниками-библиофилами. К наиболее читаемым и популярным хроникам относятся следующие произведения, созданные представителями бурятской степной аристократии: «Хоринская хроника "Предание о Бальжин-хатун"» (17601770), изданная А. М. Позднеевым [14, с. 47-55]; «История агинских бурят, написанная в 1863 г. главным тайшой агинских бурят Тугултур Тобоевым» [12, c. 5-47]; «История селенгинских бурят, написанная в 1868 г. главным тайшой селенгинских бурят Дамби-Жалцан Ломбоцыреновым» [1]; «Летопись хоринских бурят, созданная в 1875 г. главой цаганского рода, шуленгой Вандан Юмсуновым» [12, с. 49-172]; «Летопись хори-бурят, составленная в 1887 г. помощником главного тайши хоринских бурят, зайсаном галзутского рода Шираб-Нимбу Хобитуевым» (насчитывается около 30 списков данной летописи) [2]; «История баргузинских бурят, написанная в 1887 г. главным тайшой баргузинских бурят Цыдэбжаб Сахаровым» [3] и др.

Для развития ретроспективного направления в истории культуры бурят и сохранения их культурной памяти большое значение имеет изучение старописьменных памятников на широком историческом фоне и их связей с литературой средневекового Востока, кроме того, издание и переиздание редких письменных памятников бурят, а также введение в научный оборот новых неисследованных источников на монгольском письме.

В этом аспекте большой интерес представляет памятник письменной культуры бурят первой половины XX в. - анонимная рукопись летописи хоринских бурят «Qori buriyad tuqai Ača ad-tu bičigdegsen tobči teüke» ('Краткая история о хори-бурятах, написанная в Ацагате') [23].

Летопись состоит из 80 листов с текстом на монгольском письме. Содержит две части: первая - представляет собой оригинальный текст, написанный бурятским почерком позднейшего типа металлическим пером, а вторая часть - современная копия, выполненная шариковой ручкой или карандашом на тетрадных листах в клетку. Копия занимает три листа и дублирует первые страницы оригинального текста с восполнением утрат, с небольшими изменениями в лексике и орфографии.

Летопись принадлежала жителю с. Ацагат Заиграевского района Цыдыпу Раднаеву, который в 1963 г., сняв копию летописи для себя, оригинал уступил Цыбику Бобоевичу Цыдендамбаеву. В 1972 г. содержание летописи было описа- 
но в монографии Ц. Б. Цыдендамбаева «Бурятские исторические хроники и родословные». Автор охарактеризовал жанр данного письменного памятника как «исторический очерк» [19, с. 78].

Летопись не закончена и анонимна, но Ц. Б. Цыдендамбаевым было выдвинуто предположение о том, что автором исторического очерка мог быть глава худайского рода хоринских бурят Жигжит Галсанов. Возможно, текст написан со слов автора Буяном Будаевым, «человеком с хорошим почерком и быстро пишущим» [Там же, с. 81].

Автор «Ацагатского очерка» (далее - АО) в своем тексте приводит элементы устного народного творчества: легенды о Баргу-батуре, небесных девах, происхождении хори-бурят от лебедя, предание о героической княгине Бальжинхатун; народные песни о легендарной прародине хори-бурят «Наян-Наба», мужественном Шилдэй-занги, не пожелавшем оставаться в чужой стране, после установления границы между Россией и Цинской империей в 1727 г. Новым в летописной традиции бурят явилось влияние традиций русской исторической науки. Это проявилось в том, что, восприняв форму и композицию монгольских летописей, бурятские авторы стали делать ссылки на труды, которые они использовали в своем сочинении. Например, автор анонимного нарратива ссылается на труды, написанные Н. Н. Бантыш-Каменским, IV Миндол-Номун-ханом ДанзанПэрэнлэем и калмыцким князем Тюмень Чжиргалом. Это свидетельствует о том, что он хорошо владел русским, монгольским и тибетским языками.

Кроме этого, автор текста очерка использовал в своей работе личные воспоминания переводчика сибирского генерал-губернатора, графа М. М. Сперанского мещанина Василия Машанова: Ede bügüde-yi Sperangqui-yin privodči Degedü Ude-yin misinin Basiili Mošanob-un aman-ača sonusuluy=a bi [23, л. 41v.]. 'Об этом я слышал со слов переводчика Сперанского, верхнеудинского мещанина Василия Машанова'.

По-нашему предположению, личным переводчиком сибирского генералгубернатора М. М. Сперанского мог быть верхнеудинский мещанин, купец II гильдии Василий Прокопьевич Машанов (20.04.1804-?), родом из кудунских мещан, проживавший в городской усадьбе, расположенной на углу улиц Большой (Ленина) и Сенной (Свердлова), сейчас этот дом находится по улице Ленина, 15 А, где расположен магазин «Серебряный мир» [4, с. 191].

Автор литературно обработал эти воспоминания, в которых живо представлен образ графа М. Сперанского. Так, в диалогах описан его драматичный разговор с хоринскими сайтами по поводу расследования хищений общественных денег молодым тайшой Денбилом Галсановым. Эта часть текста АO, написанная со слов очевидца, придает историческому очерку характер художественного рассказа с эксплицитно невыраженным юмором.

Далее события описываются в хронологическом порядке, приводятся повествования о реальных исторических лицах: о тайше Дамдугаре Ринцееве, о судьбе знаменитой Чойжид-хатун, вовлеченной в водоворот политических событий, в борьбу за власть, описаны также и другие хоринские тайши, повествование заканчивается волостной реформой 1901-1904 гг. В данном историческом очерке события, факты и явления общественной жизни бурят излагаются в со- 
провождении прямого истолкования их автором, воспроизводятся реальные исторические лица, факты, случаи, события, увиденные автором, или описываются со слов очевидцев.

С точки зрения коммуникативной задачи это историческое сочинение относится к классу информирующих текстов с элементами активизирующих текстов, в частности к текстам научно-популярного характера, знакомящим читателя со знаниями, добытыми путем исследования и анализа, отчасти путем прагматических умозаключений.

Жители с. Ацагат, а именно Цыдып Раднаев, Дампил Базаров, Гашин Цоктоев, а также жительница села Нижняя Курба Дари Жамбалдоржиева - жена родственника Ж. Галсанова, - единодушно высказали свое мнение Ц. Б. Цыдендамбаеву (во время его экспедиции в Заиграевском районе) о том, что автором данного сочинения мог быть именно Жигжит Галсанов, глава Худайского рода хоринских бурят, который обладал широкими познаниями в области истории бурятского народа, истории их расселения, был превосходным рассказчиком, занимался литературным творчеством [19, с. 81].

Им сложены торжественные оды (магтаaль) в честь приезда царственных особ в Забайкалье и посвящены цесаревичу Николаю Александровичу во время его посещения агинских и хоринских бурят с 16 по 20 июня 1891 г. Эти оды «Хвалебная песнь наследнику Николаю» были исполнены непосредственно при встрече цесаревича Николая Александровича. Перевод гимнических песен с монгольского письма на русский язык был осуществлен другим бурятским деятелем, главой барун-хубдутского рода Эрдэни Вамбоцыреновым, последним хоринским тайшой (1898-1903 гг.), возглавившим движение «стародумцев» против введения волостного правления [18, с. 32].

Голова худайского рода Жигжит Галсанов в 1904 г., после принятия волостной реформы, был назначен председателем суда Худайской волости, в 19171919 гг. занимал должность председателя Хоринской думы. Есть предположение, что именно в этот период он мог продиктовать задуманное им историческое повествование Буяну Будаеву, который имел хороший почерк.

Вместе с тем существует и другое предположение - автором данного сочинения мог быть и заседатель Хоринской степной думы зайсан Доржи Тарбаев (Дарбаев). Такое предположение высказано хамбо-ламой Ацагатского дацана Тарба Доржиевым ${ }^{1}$. В плане установления авторства данного памятника в дальнейшем следует провести дополнительные исследования по определению и идентификации почерков, особенностей письма летописцев и т. д. Доржи Тарбаев родился в 1778 г. в местности Хара-Ацагат. К моменту завершения написания АО к 1920-м гг. ему было бы 142 года, вряд ли возможно физически достичь такого преклонного возраста.

Относительно датировки источника следует заметить, что, хотя исторический очерк завершается событиями, относящимися ко времени введения в Забайкалье волостной реформы 1901-1904 гг., в тексте повествования упоминается факт, указывающий на более позднее время написания сочинения: «...взимать

\footnotetext{
${ }^{1}$ URL: www.selorodnoe.ru
} 
ясак ежегодно с каждой трудоспособной души мужского пола в возрасте от 18 до 50 лет по 1 рублю (серебром) 72 коп. в соответствии каждой ревизии, этот налог выплачивался вплоть до падения царской власти» (курсив наш. - Л. Б.), то есть до февраля 1917 г., поэтому дату завершения рукописи можем определить как 20-е годы XX в.

Анализ лексической системы АО показывает, что в целом в тексте использована общемонгольская лексика, но некоторые из выявленных терминов присущи только бурятскому языку (siidkelge 'разрешение', busutörülten 'инородцы', yoluba 'глава рода', tayiša 'родовой правитель, глава ведомства; председатель степной думы', müškebüri 'расследование, следствие' и др.); наблюдается большой пласт русских заимствований, калькированных слов и выражений (diputat 'депутат', gineral-gübernatur 'генерал-губернатор', imperator nigedüger Piotur qaүan 'император Петр I' и др.).

Выявлены архаичные редкоупотребительные лексемы в словаре исследуемого памятника: qouslan 'вдвоем', yarayai somu 'кизиловые стрелы', küser 'земля', yegüdkekü 'скончаться, почить', qaliqu 'скончаться, почить, умереть' (выс. стиль), jorčiqu 'отправиться, направиться, поехать', qalaqu 'отменять, изменять', külsiü saqudal 'опасный для жизни период' (астрологическое понятие), sonjizuri 'стыд, позор', bel 'подножие горы' и др.

Следует заметить, что наличие русских заимствований является одной из главных лексических особенностей исторического повествования хоринских бурят [10, с. 90-92]. Важно отметить, что в тексте памятника АО письменные формы русских заимствований в основном транскрибируются на монгольском письме, например gübernatur 'губернатор', ӥрrava 'управа', imperatur 'император', Moskv-a qotan 'город Москва', posol 'посол' и т. д., а лексические единицы, проникшие через устную речь и прошедшие фонетическую адаптацию, фиксируются в бурятском разговорном произношении, например borooš 'брошь', karamuta 'грамота', kariita 'карета', pabric 'фабрика', patiyengta 'патент', pibrali 'февраль', proyeyta 'проект', stroy 'острог', qangtor 'контора', volustnui ripuram-a 'волостная реформа' и т. д. Данные заимствованные русские лексемы относим к прямым заимствованиям, проникшим в письменный источник через устную речь.

Вместе с тем заимствованная лексика АО представляет собой лексемы не только русского, но и тибетского, санскритского, китайского (уатап - яаман 'присутственное место', jayisan - зайсан 'глава рода', lonqu - лонхо 'кувшин') и маньчжурского (janggi - занги 'глава уртона', siülingge - шүҮлингэ 'сборщик податей’) происхождения.

Исследование языка АО в аспекте грамматической нормы однозначно показывает ориентацию анонимного автора на нормы старомонгольского письменного языка [8]. Материалы исторического текста свидетельствуют о том, что он написан на монгольском письме, сочетающем в себе старомонгольскую классическую основу и влияние народной разговорной стихии бурят. В целом, на наш взгляд, язык памятника письменной культуры бурят начала XX в. представляет собой переходную гибридную форму книжного языка, сложившуюся в результате смешения письменного монгольского и разговорного бурятского языков, по- 
скольку в то время нормы создания письменных текстов не были кодифицированы.

Однако в 1931 г. осуществился переход на латинский алфавит, а в 1938 г. на кириллицу, но до 1936 г. газеты, делопроизводство частично печатались на монгольском письме [17, с. 44-46]. В дальнейшем русская графическая основа бурятского языка постепенно вытеснила монгольскую вертикальную графику, которая в 1930-е гг. под веянием новой советской идеологии подверглась сильнейшей критике как «архаичная феодально-теократическая письменность» и была объявлена «вредной, ламской письменностью, орудием панмонголистов». А литературные сочинения на монгольском письме изымались и варварски уничтожались как наследие феодально-теократического режима. Только за хранение и чтение книг на монгольском письме людей объявляли «врагами народа, панмонголистами» и бросали в застенки.

Как пишет исследователь бурятской дидактической литературы Д. Б. Дашиев, «после революции в ходе борьбы с так называемым буржуазным национализмом и панмонголизмом вся эта литература (на вертикальном монгольском письме. - Л. Б.) была объявлена антинародной и изъята из обращения. Смена письменности в последующие годы привела почти к полному забвению как авторов, так и самих памятников» $[5$, с. 3$]$.

Как отмечает проф. Л. Д. Шагдаров, «сложившаяся в настоящее время языковая ситуация в Бурятии показывает, что эта критика (старомонгольской письменности. - Л. Б.) во многом была необоснованной. Из-за того, что напрочь был отброшен в свое время старомонгольский язык, культурное наследие, созданное на нем бурятами и другими монгольскими народами, стало для бурятского народа книгой за семью печатями» [21, с. 186].

Вместе с тем невозможно оценить роль монгольского письма в культурноисторическом процессе развития бурятского этноса и цивилизационном его значении для культуры монгольских народов. Представляется, что смена типов визуальной коммуникации повлекла за собой забвение монгольского письма и его памятников, что отрицательно сказалось на дальнейшем развитии бурятского языка и культуры. Из-за гонений и запрета своей исторической письменности бурятский народ получил «культурную травму», последствия которой отразились на современном состоянии бурятского языка. Между тем письменные памятники на вертикальной монгольской графике, безусловно, являются неотъемлемой частью культурного достояния бурят.

\section{Литература}

1. Шагдаров Л. Д., Бадмаева Л. Б. Язык и стиль селенгинской летописи Д.-Ж. Ломбоцыренова «История селенгинских монголо-бурят». Улан-Удэ: Изд-во БНЦ СО РАН, 2014. $216 \mathrm{c}$.

2. Бадмаева Л. Б., Очирова Г. Н. Летопись Ш.-Н. Хобитуева как памятник письменной культуры бурят. Улан-Удэ: Бэлиг, 2018. 288 с.

3. Востриков А. И., Поппе Н. Н. Летопись баргузинских бурят. Вып. 1. Тексты и исследования // Тр. Института востоковедения. М.; Л.: Изд-во АН СССР, 1935. Т. VIII. $75 \mathrm{c}$. 
4. Гурьянов В. К., Гурьянов М. В. Верхнеудинск XVII - начала XX вв. Улицы, городские усадьбы и их обитатели. Улан-Удэ: Изд-во БНЦ СО РАН, 2012. 224 с.

5. Дашиев Д. Б. Бурятская дидактическая литература: проблемы жанрового состава: автореф. дис. ... канд. филол. наук. Улан-Удэ, 1997. 15 с.

6. Доржиев Д. Д. Язык старомонгольской письменности Бурятии: автореф. дис. ... канд. филол. наук. М., 1955. 18 с.

7. Доржиев Д. Д. Старобурятский язык. Улан-Удэ, 1992. 244 с.

8. Жамсоев А. Д. Категория склонения в языке летописи «Ацагатский очерк о хорибурятах» // Ученые записки Забайкальского государственного университета. Чита: Забайкальский государственный университет, 2015. С. 146-151.

9. Жамсоев А. Д. «Ацгадын товч түүх» дэх Шилдэй зангийн дууны гар бичмэлийн тухай // Монгол бичгийн сурвалж судлал: сб. тез. междунар. науч. конф. Улан-Батор: Институт монголоведения МонГу, 2015. С. 22-23.

10. Жамсоев А. Д. Русские лексические заимствования европейского происхождения в тексте «Ацагатского очерка» // Филологические науки: вопросы теории и практики. Тамбов, 2017. С. 90-92.

11. Жамсоев А. Д. Отражение разговорного языка в «Песне Шилдэй занги» в тексте «Ацагатского очерка о хори-бурятах» // Вестник Бурятского государственного университета. Улан-Удэ: Изд-во Бурят. гос. ун-та, 2017. С. 10-19.

12. Летописи хоринских бурят. Вып. 1. Хроники Тугултур Тобоева и Вандана Юмсунова // Тр. Института востоковедения. Текст издал Н. Н. Поппе. Т. IX. М.; Л.: Изд-во AH CCCP, 1935. $172 \mathrm{c}$.

13. Очирова Г. Н. Хори буряадууд тухай Асагадта бэшэгдэһэн тобшо түүхэ // Морин хуур. № 5-6 (13-14). Улан-Удэ: Буряад үнэн, 2001. Х. 102-124.

14. Позднеев А. М. Монгольская хрестоматия для первоначального преподавания. СПб., 1900. $416 \mathrm{c.}$

15. Румянцев Г. Н. Бурятские летописи как исторический источник // Тр. БКНИИ СО АН СССР. Сер. востоковедная. Вып. 3. Улан-Удэ: Бур. кн. изд-во, 1960. С. 3-15.

16. Санжанов Ж. Ш. Общественно-политическая лексика бурятского языка в 20-30-е гг. ХХ в.: автореф. дис. ... канд. филол. наук: 10.02.02. М., 2019. 26 с.

17. Санжеев Г. Д. Сравнительная грамматика монгольских языков. М.: Изд-во АН CCCP, 1953. Т. I. 240 c.

18. Фролова Г. «Богдо-наследник Николай» в хвалебных песнях бурят // Восточная коллекция. 2004. № 3. С. 29-33.

19. Цыдендамбаев Ц. Б. Бурятские исторические хроники и родословные. Улан-Удэ: Бурят. кн. изд-во, 1972. 662 с.

20. Шагдаров Л. Д. Старописьменный язык и формирование бурятского литературного языка // Всесоюз. науч. конф., посвященная 100-летию со дня рождения акад. Б. Я. Владимирцова. М., 1984. С. 120-122.

21. Шагдаров Л. Д. Г. Ц. Цыбиков об использовании старомонгольского языка в качестве литературного языка бурят // Цыбиковские чтения: тез. докл. и сообщений. УланУдэ, 1989. С. 183-187.

22. История бурятской книги [Электронный ресурс]: справочно-библиографический CD / науч. ред. Л. Б. Бадмаева [и др.]. Улан-Удэ, 2009. 2 эл. опт. диска (CD-ROM).

23. Qori buriyad tuqai Ačayad-tu bičigdegsen tobči teüke="Ацагатский очерк о хорибурятах’. ЦВРК ИМБТ СО РАН. Ф. 485, оп. 1, д. 13. Рукопись. 


\section{WRITTEN HERITAGE OF THE BURYATS IN THE OLD MONGOLIAN SCRIPT}

\section{Larisa B. Badmaeva}

Dr. Sci. (Phil.), A/Prof., Leading Researcher, Linguistics Department, Institute for Mongolian, Buddhist and Tibetan Studies SB RAS 6 Sakhyanovoy St., Ulan-Ude 670047 Russia lorabadm@mail.ru

Abstract. The article explores the written heritage of the Buryats in the Old Mongolian script, which for a long time was a common Mongolian literary language, starting from the 12th century. The Buryats have been used it as a written literary language since the 17 th century until 1936. There were created unique compositions of different genres in the Mongolian script. In addition, the paperwork was carried out and newspapers and magazines were published in this script. The genre of historical chronicles is the most developed. The tradition of chronicle writing among the Buryats was continued in the 20th century. A previously unexplored anonymous written monument of the 1920s the "Atsagat essay on the Khori-Buryats" is described. This essay, based on the combination of the traditions of Mongolian chronicles and Russian historical science, with elements of Buryat folklore, ethnography, eyewitness memories, the author's own observations, is a synthesis of genres of historical, literary, memoir nature. The change in writing in subsequent years led to the complete oblivion of both the authors and the monuments themselves. Meanwhile, these written sources, being a reflection of the linguistic picture of the Mongolian world, are of great interest to historians, philologists, and culturologists. Keywords: the Old Mongolian script; written monuments of the Buryats; the Buryat chronicles; anonymous written monument "Atsagat essay on the Khori-Buryats".

Статья поступила в редакичию 26.10.2020; одобрена после рецензирования 13.11.2020; принята к публикаичии 01.12.20. 